\title{
PENGARUH PENGGUNAAN WHEY DAN FESES SAPI MADURA SEBAGAI SUBSTRAT BIOGAS TERHADAP PRODUKSI METAN, KECERNAAN BAHAN ORGANIK DAN pH SLURRY
}

\author{
THE USE OF WHEY AND MADURA CATTLE DUNG AS SUBSTRATE IN THE BIOGAS \\ DIGESTER ON THE METHANE PRODUCTION, VOLATILE SOLID REDUCTION AND $p H$ \\ SLURRY
}

\author{
N. Krisdianty, A. Purnomoadi dan Sutaryo \\ Fakultas Peternakan dan Pertanian Universitas Diponegoro, Semarang \\ Email: n.krisdianty@gmail.com
}

\begin{abstract}
The purpose of this research was to evaluate the use of whey as substrate on the methane production, volatile solid (VS) reduction and $\mathrm{pH}$ slurry. This study used a Completely Randomized Design (CRD) with 2 treatments $\left(T_{1}\right.$ : digester treating Madura cattle dung and water (FA) and $T_{2}$ : digester treating Madura cattle dung and whey $(F W)$ with a ratio of 1:1). The replication was the collected data from 2 hydraulic retention times. The data were analysed using t-test. The result of research showed that there were significant differences $(P<0.05)$ on the methane production between the treatments. The methane production of $F W$ and FA were 1465 and $613 \mathrm{ml} / \mathrm{l}$ digester volume. VS reduction of $F A$ and $F W$ were $31.53 \% ; 37.45 \%$, while $\mathrm{pH}$ slurry of FA and FW were 6.86; 6.88, respectively. This study concluded that the whey can be use to increase methane production of Madura cattle dung.
\end{abstract}

Key word: dung, methane, $p H$, VS reduction, whey

\section{ABSTRAK}

Tujuan penelitian ini adalah untuk mengetahui dampak penggunaan whey dalam substrat biogas terhadap rata-rata produksi metan, kecernaan bahan organik $(\mathrm{KcBO})$ dan $\mathrm{pH}$ slurry. Rancangan percobaan menggunakan Rancangan Acak Lengkap (RAL) dengan 2 perlakuan yaitu $\mathrm{T}_{1}$ dengan bahan isian feses sapi Madura dicairkan dengan air (FA) dan $\mathrm{T}_{2}$ dengan bahan isian feses sapi Madura dicairkan dengan whey (FW) dengan perbandingan 1:1. Ulangan yang dilakukan berupa pengambilan data selama 2 kali hydraulic retention time. Analisis data menggunakan t-test. Hasil penelitian menunjukkan bahwa terdapat perbedaan nyata $(\mathrm{P}<0,05)$ dari perlakuan penggunaan whey terhadap produksi metan. FW menunjukkan produksi metan yang lebih besar dibandingkan dengan FA (1465 vs 613 ml/l volume digester aktif), untuk KcBO antara FA dan FW (31,53\% vs 37,45\%) dan $\mathrm{pH}$ slurry antara FA dan FW $(6,86$ vs 6,88$)$ menunjukan hasil tidak berbeda nyata $(\mathrm{P}>0,05)$. Whey berpotensi untuk digunakan sebagai bahan pencair feses sapi Madura pada pembuatan biogas untuk mengoptimalkan produksi metan.

Kata kunci : feses, $\mathrm{KcBO}$, metan, $\mathrm{pH}$, whey

\section{PENDAHULUAN}

Usaha peternakan memiliki prospek keuntungan yang besar dan perlu dikembangkan dikarenakan tingginya permintaan akan produk peternakan. Peningkatan permintaan produk hasil ternak mendorong meningkatnya populasi dan produktivitas ternak. Berkembangnya kegiatan usaha peternakan juga memberikan dampak negatif yaitu semakin besarnya volume limbah yang dihasilkan (Wahyuni, 2008). Simamora et al., (2006) menyatakan bahwa seekor sapi dengan berat badan $454 \mathrm{~kg}$ dapat menghasilkan feses sebanyak 30 $\mathrm{kg} / \mathrm{hari}$. Feses ternak dalam jumlah besar dapat menjadi sumber pencemaran dan menyebabkan terjadinya kerusakan lingkungan hidup. Oleh karena itu penanganan feses harus ditangani secara serius sehingga dapat meminimalisir masalah yang ditimbulkan dan dapat memberikan manfaat bagi masyarakat luas.

Feses ternak dominan akan bahan organik yang dengan pengolahan teknologi sederhana dapat diupayakan menghasilkan biogas (Saleh, 2004). Biogas merupakan gas campuran metana $\left(\mathrm{CH}_{4}\right)$, karbondioksida $\left(\mathrm{CO}_{2}\right)$ dan gas lainnya. Gas ini dihasilkan oleh proses degradasi anaerobik dari bahan organik oleh mikroorganisme (Haryati, 2006). Agar produksi biogas dari feses dapat tercapai dengan optimal, perlu diupayakan penambahan bahan lain yang mampu 
mempengaruhi produksi metan dan kecernaan yang lebih baik dari feses sapi.

Agar dapat beraktifitas secara optimal, mikroba penghasil biogas memerlukan substrat dengan kadar air $90 \%$ dan kadar padatan $8-10 \%$. Bahan baku berkadar air rendah dapat diencerkan dengan menambahkan bahan pencair ke dalamnya (Sidik, 2008). Bahan pencair yang digunakan dapat berupa air, tetapi agar dapat berjalan optimal maka perlu bahan pencair yang mampu mengoptimalkan pembentukan biogas. Whey susu merupakan bahan organik cair yang terbuang dari proses pembuatan keju yang merupakan polutan terbesar dari air limbah produksi keju. Disisi lain, whey masih memiliki nilai nutrisi yang tinggi termasuk protein, lipid, mineral, vitamin dan laktosa (Azizah et al., 2012). Kandungan bahan organik dalam whey bersifat biodegradable yang berpotensi untuk diolah menjadi biogas dengan cara degradasi anaerobik dan dapat menunjang atau mempengaruhi kecernaan bahan organik $(\mathrm{KcBO})$ serta produksi metan yang dihasilkan. Mudah tidaknya suatu bahan organik untuk dicerna oleh mikroorganisme akan berpengaruh pada produksi senyawa antara proses hidrolisis dan metanogenesis dalam hal ini adalah asam-asam organik. Kandungan asam-asam organik dalam sistem anaerobik dapat mempengaruhi $\mathrm{pH}$ slurry yang menjadi indikator baik-buruknya performa dalam digester serta sebagai faktor yang mempengaruhi aktivitas dan perkembangbiakan bakteri pembentuk biogas. $\mathrm{pH}$ ideal dibutuhkan untuk mengoptimalkan aktivitas mikroorganisme agar bahan organik dalam substrat dapat termanfaatkan dengan maksimal sehingga dicapai produksi metan yang maksimal pula. Selain itu, protein yang terkandung dalam whey dapat mempengaruhi ratio $\mathrm{C} / \mathrm{N}$ substrat yang merupakan faktor yang memengaruhi produksi metan. Bakteri metanogenik akan bekerja optimal pada rasio $\mathrm{C} / \mathrm{N}$ sebesar 2535. Feses sapi memiliki rasio $\mathrm{C} / \mathrm{N}$ berkisar 24 (Simamora et al., 2006). Whey memiliki rasio C/N sebesar 22 (Korres et al., 2013).

Tujuan penelitian ini yaitu untuk mengetahui dampak penggunaan whey susu dalam substrat biogas dengan bahan baku feses sapi madura terhadap rata-rata produksi metan, Kecernaan bahan organik (KcBO) dan $\mathrm{pH}$ slurry. Manfaatnya yaitu diharapkan dapat memberikan dampak positif dari penggunaan whey pada pembuatan biogas dengan bahan baku feses sapi Madura sehingga akan menghasilkan produksi biogas yang optimal serta performa dalam digester yang baik pula.

\section{METODE PENELITIAN}

\section{Bahan dan Alat}

Bahan yang digunakan yaitu feses sapi Madura, whey susu dari perusahaan keju Indrakila Kabupaten Boyolali dan air sebagai bahan pencair feses serta larutan $\mathrm{NaOH} 4 \%$ (w/w). Alat yang digunakan adalah tabung pencerna, selang teflon, karet penutup, botol kaca, keran plastik, tedlar gas bag, bak penampung air, pompa air, gelas ukur kapasitas $1000 \mathrm{ml}$, rangkaian kayu penyangga, malam, corong, $\mathrm{pH}$ meter, timbangan digital, timbangan analitik, gelas beker, freezer, refrigerator, oven dan tanur.

\section{Tahapan Penelitian}

Tahap penelitian meliputi persiapan materi dan pelaksanaan penelitian. Tahap pengujian variabel meliputi pengamatan produksi metan, kecernaan bahan organik (KcBO) dan pH slurry. Selain itu dilakukan pengujian terhadap data pendukung berupa kandungan bahan organik dan rasio $\mathrm{C} / \mathrm{N}$ dari substrat isian digester.

\section{Rancangan Penelitian}

Rancangan percobaan yang digunakan dalam penelitian ini adalah Rancangan Acak Lengkap (RAL) dengan 2 perlakuan berupa $\mathrm{T}_{1}$ yaitu bahan isian digester berupa feses sapi Madura yang dicairkan dengan air (FA) dan $\mathrm{T}_{2}$ yaitu bahan isian digester berupa feses sapi Madura yang dicairkan dengan whey (FW) dengan perbandingan 1:1. Ulangan yang dilakukan berupa pengambilan data selama 2 hydraulic retention time (HRT) dimana 1 kali HRT yaitu selama 25 hari.

Persiapan penelitian berupa pengumpulan feses. Kemudian pembuatan starter dilakukan dengan mencampurkan dan mengaduk feses sapi dan air dengan perbandingan 1:1 sampai homogen. Starter 
disimpan dalam drum dalam kondisi anaerob dan didiamkan selama 3 minggu. Selanjutnya pembuatan dua unit rangkaian digester biogas model continous feeding dan merangkai alat pengukur produksi gas. Peralatan untuk membuat dua unit rangkaian digester adalah tabung pencerna yang terbuat dari stainles, selang teflon, penutup karet, botol kaca sebagai tempat larutan $\mathrm{NaOH} 4 \%$ (w/w) dan tedlar gas bag sebagai alat untuk menangkap gas. Alat untuk mengukur produksi gas terdiri dari gelas ukur kapasitas $1000 \mathrm{ml}$, selang teflon, keran plastik, rangkaian kayu penyangga, bak air dan pompa air.

Sebelum dilakukan pengambilan data, terlebih dahulu dilakukan adaptasi selama 3 minggu. Adaptasi dilakukan dengan cara mengisi digester dengan starter sebanyak $80 \%$ volume digester. Kemudian setiap hari dilakukan pengeluaran slurry dan pengisian substrat sebanyak $244 \mathrm{~g}$ berdasarkan perhitungan volume digester aktif $(5600 \mathrm{ml})$ dibagi dengan waktu 1 HRT (25 hari). Pengukuran produksi metan dilakukan pada 5 hari terakhir periode adaptasi. Apabila produksi metan telah stabil maka penelitian utama telah dapat dilakukan.

Dua unit rangkaian digester biogas selanjutnya diisi dua bahan isian yang berbeda yaitu antara campuran feses sapi Madura dengan whey dan dengan air. Berdasarkan cara pengisiannya dilakukan dengan cara pengisian kontinyu dimana pengisian bahan isian dilakuakan setiap hari.

\section{Analisis Data}

Selanjutnya melakukan pengamatan terhadap produksi metan harian selama 2 HRT dengan menggunakan liquid displacement method, analisis $\mathrm{KcBO}$ dilakukan satu minggu sekali dan pengukuran $\mathrm{pH}$ slurry yang dilakukan sebanyak 2 kali dalam satu minggu. Data yang terkumpul kemudian dianalisis menggunakan t-test dengan aplikasi SPSS Statistics 21 untuk mengetahui apakah data hasil pengukuran dari kedua perlakuan memiliki rata-rata yang berbeda.

\section{HASIL DAN PEMBAHASAN}

\section{Pengaruh Penggunaan Whey terhadap Produksi Metan}

Rata-rata produksi metan dari digester dengan bahan isian feses yang dicairkan dengan air (FA) dan dengan bahan isian feses yang dicairkan dengan whey (FW) selama 2 Hydraulic Retention Time (HRT) disajikan dalam Gambar 1.

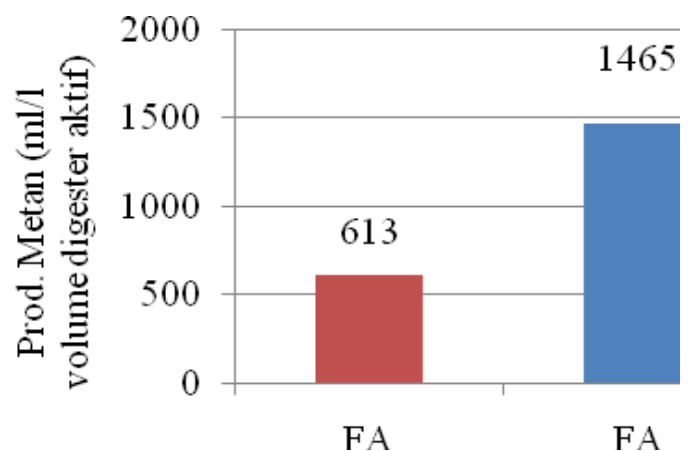

Gambar 1. Rata-rata Produksi Metan pada FA dan FW Selama 2 HRT

Gambar 1 menunjukkan bahwa ratarata produksi metan dari digester dengan bahan isian FW didapatkan hasil yang lebih tinggi dibandingkan FA. Secara statistik menunjukkan adanya perbedaan yang nyata $(\mathrm{P}<0,05)$ dari perlakuan penggunaan whey sebagai bahan pencair feses terhadap produksi metan yang dihasilkan. Selisih produksi metan antara FA dan FW yaitu sebesar $852 \mathrm{ml} / \mathrm{l}$ volume digester aktif atau sekitar 138\%. Hal tersebut menunjukkan bahwa penggunaan whey sebagai bahan pencair feses dapat meningkatkan volume metan yang dihasilkan hingga mencapai 1,3 kali lebih banyak dibandingkan dengan pencairan menggunakan air.

Perbedaan kandungan bahan organik dalam bahan isian digester berpengaruh terhadap produktivitas mikroorganisme dan produksi metan yang dihasilkan. Menurut Syahputra (2009), bakteri yang terlibat dalam proses anaerobik membutuhkan beberapa elemen sesuai dengan kebutuhan organisme hidup seperti sumber makanan dan kondisi lingkungan yang optimum. Semakin banyak bahan organik yang terkandung dalam bahan isian digester akan lebih mudah dicerna oleh mikroorganisme, menyebabkan produksi metan semakin tinggi. Hasil analisis bahan 
organik dari substrat FA dan FW menunjukkan angka sebesar 9,19\% dan $12,02 \%$. Whey memiliki bahan organik sebesar 5,63\%, sehingga kandungan bahan organik yang dapat dimanfaatkan oleh mikroorganisme untuk menghasilkan metan lebih banyak pada FW dibandingkan dengan FA, serta berdasarkan hasil penelitian terbukti bahwa produksi metan yang dihasilkan pada digester dengan bahan isian FW tersebut lebih besar.

Yani dan Darwis (1990) berpendapat bahwa mikroba yang berperan dalam proses anaerobik membutuhkan nutrisi untuk tumbuh dan berkembang, berupa sumber karbon dan sumber nitrogen. Tabel 1 menunjukkan rasio $\mathrm{C} / \mathrm{N}$ dari bahan baku substrat isian digester.

Kandungan protein dalam whey menyebabkan penurunan rasio $\mathrm{C} / \mathrm{N}$ dari feses karena terjadi penambahan kandungan nitrogen dalam bahan isian digester. Berdasarkan hasil penelitian, penurunan rasio $\mathrm{C} / \mathrm{N}$ pada substrat $\mathrm{FW}$ tidak menyebabkan rendahnya produksi metan yang dihasilkan. Hal tersebut menunjukkan bahwa penurunan rasio $\mathrm{C} / \mathrm{N}$ akibat peningkatan kandungan nitrogen pada substrat FW dalam penelitian ini tidak menyebabkan terjadinya akumulasi ammonia yang dapat mengganggu aktivitas mikroorganisme. Dapat disimpulkan pula bahwa level pemberian whey dalam penelitian ini masih dalam batas baik.

Menurut Simamora et al. (2006), bakteri metanogenik akan bekerja optimal pada nilai rasio $\mathrm{C} / \mathrm{N}$ sebesar 25-35. Jika dibandingkan dengan rasio tersebut, rasio $\mathrm{C} / \mathrm{N}$ pada $\mathrm{FA}$ dan $\mathrm{FW}$ yang bernilai sekitar 13-14 dapat dikatakan belum optimal. Hal tersebut dibuktikan dengan rata-rata nilai kecernaan bahan organik pada $\mathrm{FW}$ yaitu berkisar $37 \%$. Apabila rasio $\mathrm{C} / \mathrm{N}$ dalam kondisi yang optimal dapat memungkinkan memberikan nilai kecernaan bahan organik yang lebih tinggi.

Pengaruh Penggunaan Whey terhadap Kecernaan Bahan Organik (KcBO)

Nilai kecernaan bahan organik (KcBO) beserta perubahannya dari minggu ke minggu pada digester dengan substrat FA dan FW disajikan dalam Gambar 2.

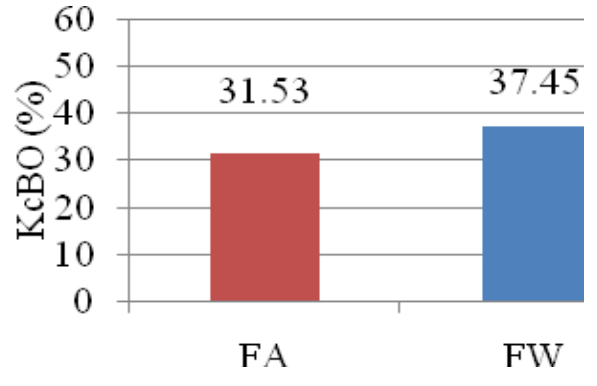

(a)

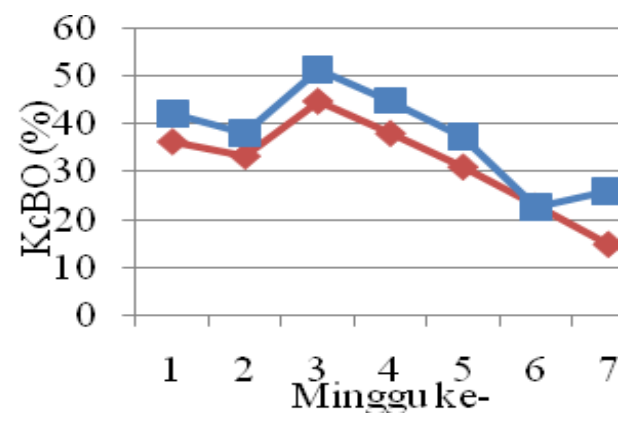

(b)

Gambar 2. Nilai KcBO dari FA dan FW (a), dan perubahan $\mathrm{KcBO}$ dari FA dan FW (b).

Menurut Babaee and Shayegan (2011), kecernaan bahan organik merupakan aspek penting dalam mengevaluasi kinerja pencernaan secara anaerobik dalam digester pada proses pembuatan biogas. Dari Gambar 2a tampak bahwa KcBO pada substrat FW lebih tinggi dibandingkan dengan substrat FA, artinya bahwa penggunaan whey sebagai bahan pencair feses memberikan kemampuan mencerna bahan organik yang lebih besar bagi mikroorganisme untuk merubahnya menjadi metan. Rentang persentase KcBO dari substrat FA dan FW masing-masing berkisar 14,97\% - 44,57\% dengan rata-rata $31,53 \%$ dan $22,73 \%$ - $51,18 \%$ dengan ratarata $37,45 \%$.

Namun, secara statistik menunjukkan hasil tidak berbeda nyata $(\mathrm{P}>0,05)$ antara $\mathrm{KcBO}$ pada FA dan KcBO pada FW. Hal tersebut karena adanya ketentuan waktu pengisian digester kontinyu selama 24 jam untuk megeluarkan slurry dan menambahkan dengan substrat yang baru. Karena adanya ketentuan waktu pengisian substrat baru tersebut memberikan dampak terbatasnya 
Tabel 1. Rasio C/N dari bahan baku substrat isian digester

\begin{tabular}{lc}
\hline \multicolumn{1}{c}{ Jenis Bahan } & Rasio C/N (\%) \\
\hline Feses & 15,245 \\
Whey & 16,92 \\
$\begin{array}{l}\text { Substrat feses + air } \\
\text { Substrat feses + } \\
\text { whey }\end{array}$ & 14,72 \\
\hline
\end{tabular}

waktu untuk mencerna bahan oranik sehingga menyebabkan kecilnya selisih $\mathrm{KcBO}$ dari FA dan FW dan tidak memunculkan perbedaan secara nyata.

Gambar 2b menunjukkan terjadinya penurunan $\mathrm{KcBO}$ pada $\mathrm{FA}$ dan $\mathrm{FW}$ dari minggu ke minggu. Hal tersebut diduga disebabkan oleh umur feses yang dimasukkan dalam digester akibat waktu penyimpanan feses yang semakin lama, sehingga memungkinkan terjadinya penurunan kualitas terutama kandungan bahan organik di dalamnya. Selama waktu penyimpanan substrat diduga terjadi degradasi yang tidak terkontrol oleh mikroorganisme yang terjadi diluar digester yang secara alami terdapat dalam feses tersebut. Sesuai dengan pendapat Meynell (1976) bahwa pada feses sapi telah mengandung bakteri penghasil metan yang terdapat dalam perut sapi sebagai ternak ruminansia. Selain itu juga dimungkinkan karena terjadinya penurunan suhu yang tidak terkontrol saat dilakukannya penelitian. Suhu merupakan faktor yang berpengaruh terhadap aktivitas mikroorganisme. Berdasarkan pengukuran suhu mikro diperoleh hasil rataan suhu pada bulan November dan Desember 2013 saat dilakukannya penelitian utama yaitu $29^{\circ} \mathrm{C}$ dan $27^{\circ} \mathrm{C}$. Darmanto et al., (2012) berpendapat bahwa temperatur yang lebih tinggi atau lebih rendah dari batas yang dapat ditolerir akan menyebabkan aktivitas mikroorganisme akan terganggu.

\section{Pengaruh Penambahan Whey terhadap pH Slurry}

Hasil analisis menunjukkan bahwa nilai pH slurry pada FA berkisar 6,79-7,07 dengan rata-rata sebesar 6,86, sedangkan pada FW berkisar 6,69-6,99 dengan rata-rata sebesar 6,88 dan dapat dikatakan berada pada kisaran pH ideal (Gambar 3). Proses anaerobik yang ideal berjalan pada $\mathrm{pH}$ sekitar 6,5-7,6
(Rittmann dan McCarty, 2001) dengan pH optimal berkisar antara 7,0-7,2 (Polprasert, 1995). Secara statistik tidak terdapat perbendaan secara nyata $(\mathrm{P}>0,05)$ antara $\mathrm{pH}$ slurry pada FA dan $\mathrm{pH}$ slurry pada FW.

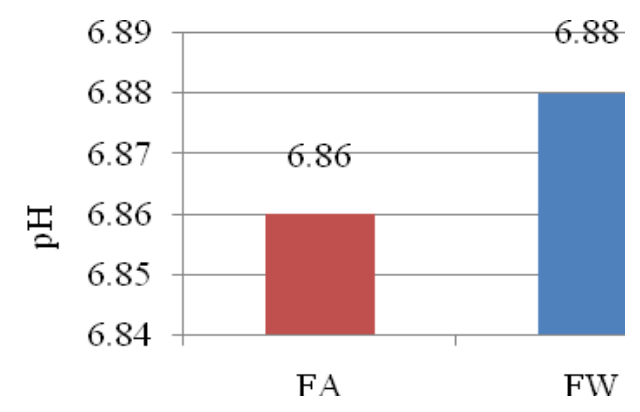

Gambar 3. Rata-rata Nilai pH Slurry

Kondisi pH berpengaruh terhadap pertumbuhan dan aktivitas mikroorganisme untuk mencerna bahan organik dalam substrat biogas sehingga akan menghasilkan metan. Melihat kondisi pH slurry dari kontrol dan perlakuan tersebut maka pertumbuhan dan aktivitas mikroorganisme di dalam digester dapat dikatakan berjalan dengan optimal. Menurut Saputra et al. (2010), kondisi pH berpengaruh pada pertumbuhan mikrobia anaerobik dalam menghasilkan biogas terutama metan.

\section{KESIMPULAN}

Kesimpulan dari penelitian ini adalah adanya pengaruh penggunaan whey sebagai bahan pencair feses pada pembuatan biogas sehingga meningkatkan produksi metan yang dihasilkan tetapi tidak memberikan pengaruh terhadap KcBO dan $\mathrm{pH}$ slurry. Whey berpotensi untuk digunakan sebagai bahan pencair feses pada pembuatan biogas untuk mengoptimalkan produksinya.

\section{DAFTAR PUSTAKA}

Azizah, N., A. N. Al-Baarri dan S. Mulyani. 2012. Pengaruh Lama Fermentasi Terhadap Kadar Alkohol, pH, dan Produksi gas pada Proses Fermentasi Bioetanol dari Whey dengan Substitusi Kulit Nanas. Jurnal Aplikasi Teknologi Pangan. 1 (2): 72-77.

Babaee, A. and J. Shayegan. 2011. Effect of 
Organic Loading Rate (ORL) on Production of Methane from Anaerobic Digestion of Vegetables Waste. World Renewable Energy Congress, Sweden.

Budihardjo, M.A. 2009. Kombinasi Feeding Biostarter dan Air dalam Anaerobik Digester. Jurnal Presipitasi. 6 (2): 2734.

Darmanto, A., S. Soeparman dan D. Widhiyanuriawan. 2012. Pengaruh Kondisi Temperatur Mesophilic $\left(35^{\circ} \mathrm{C}\right)$ dan Thermophilic $\left(55^{\circ} \mathrm{C}\right)$ Anaerob Digester Kotoran Kuda terhadap Produksi Biogas. Rekayasa Mesin. 3 (2): 317-326.

Haryati, T. 2006. Biogas: Limbah Peternakan yang Menjadi Sumber Energi Alternatif. Wartazoa. 16 (6): 160-169.

Korres, N.E., P. O'Kiely, J.A.H. Benzie, and J.S. West. 2013. Bioenergy Production by Anaerobic Digestion. Routledge, Canada.

Meynell, P.J. 1976. Methane: Planing a Digester. Prism Press, Great Britain.

Polprasert, C. 1995. Organic Waste Recycling. Environmental Engine, Asian Institute of Technology, Thailand.

Rittman, B.E. and P.L. McCarty. 2001. Environmental Biotechnology: Principles and Applications. The McGraw-Hill Companies, New York.

Saleh, E. 2004. Teknologi Pengolahan Susu dan Hasil Ikutan Ternak. Universitas Sumatera Utara, Medan.

Saputra, T., S. Triatmojo dan A. Pertiwiningrum. 2010. Produksi Biogas dari Campuran Feses Sapi dan Ampas Tebu (Bagasse) dengan Rasio $\mathrm{C} / \mathrm{N}$ yang Berbeda. Buletin Peternakan. 34 (2): 114-122.

Sidik, P. 2008. Perbandingan Unjuk Kerja Proses Fermentasi Anaerobik Single Stage dengan Double Stage Sebagai Alternatif Pengolahan Sampah Kota. Institut Teknologi Nasional, Bandung. (Skripsi Sarjana Teknik).
Simamora, S., Salundik, S. Wahyuni dan Surajudin. 2006. Membuat Biogas Pengganti Bahan Bakar Minyak dan Gas. AgroMedia Pustaka, Jakarta.

Syahputra, A. 2009. Produksi Gas Bio dari Campuran Kotoran Sapi Perah dengan Kompos Jerami Padi pada Rasio C/N yang Berbeda. Fakultas Peternakan, Institut Pertanian Bogor.

Wahyuni, S. 2008. Biogas. Penebar Swadaya, Jakarta.

Yani, M. dan A.A. Darwis. 1990. Diktat Teknologi Biogas. Pusat Antar Universitas Bioteknologi Institut Pertanian Bogor, Bogor. 